\title{
ASYMPTOMATIC WALDENSTROM'S MACROGLOBULINEMIA IN A YOUNG ADULT
}

\author{
Abdul N. Memon, M.D.*
}

\section{Summary}

We report a case of WM which is unusual in two respects: the patient was 36-years-old and was asymptomatic at diagnosis. Because of the young age of our patient, WM was not an initial consideration and was a somewhat surprising finding. However, upon review of the literature on WM, it appears that approximately $5 \%$ of the patients with WM are between $30-40$ years of age. ${ }^{456}$ The percentage of these young patients who were asympotmatic at diagnosis, such as our patient, is impossible to determine from the published data.

Waldenstrom's macroglobulinemia (WM) is a neoplastic disorder of B lymphocytes, which are intermediate in differentiation between mature lymphocytes and plasma cells and which synthesize and secrete monoclonal IgM'. Most patients with WM seek medical care because of symptoms due to high levels of circulating paraprotein (i.e. hyperviscosity), lymphadenopathy, hepatosplenomegaly, or bone marrow hypofunction caused by infiltrating neoplastic cells.

\section{Case Report}

A 36-year-old white female was hospitalized for dehydration resulting from nausea and vomiting due to gastroenteritis. Her past medical history was unremarkable except for infectious mononucleosis seven years previously. Physical examination revealed no abnormality except signs of dehydration. The fundi were unremarkable. There was no lymphadenopathy or hepatosplenomegaly.

Laboratory data included a hemoglobin of 10 $\mathrm{g} \%$, WBC 5700/cumm with a normal differential count, platelets $288,000 /$ cumm, and erythrocyte sedimentation rate (ESR) $66 \mathrm{~mm} / \mathrm{hr}$. Other chemistry tests were normal. Her dehydration was corrected with intravenous fluids and with oral feedings. Gastrointestinal evaluation and roentgenograms were negative for malabsorption or intestinal pathology. Before her anemia could be evaluated, she was discharged at her insistence.

During the nine subsequent months, the patient was asymptomatic. A hematological evaluation at the time showed a hemoglobin of $11.4 \mathrm{~g} \%$, WBC $6600 /$ cumm, platelets $316,000 /$ cumm, serum viscosity 2.6 , and ESR $116 \mathrm{~mm} / \mathrm{hr}$. Coagulation and iron studies were normal and hemolysis work-up

\footnotetext{
-Internist (Diplomate, ABIM) Oncologist (Diplomate, ABIM), The Memorial Hospital. Pawtucket, R.I.
}

(including Coomb's testing) was negative. A bone marrow aspirate and biospy revealed a normal cellularity with increased plasma cells, lymphocytes, and plasmacytoid lymphocytes consistent with Waldenstrom's macroglobulinemia. Gallium scan and liver-spleen scan were normal. A serum protein electrophoresis showed an albumin of 4.1 $\mathrm{g} / \mathrm{dl}$ and globulin of $2.7 \mathrm{~g} / \mathrm{dl}$ with monoclonal spike (Fig. 1). Quantitative immunoglobulin analysis revealed an IgG of $430 \mathrm{mg} / \mathrm{dl}$, IgA $62 \mathrm{mg} / \mathrm{dl}$, and Igm $4200 \mathrm{mg} / \mathrm{dl}$. An immunoelectrophoresis demonstrated a monoclonal IgM of the kappa type (Fig. 1). Additional chemistry studies were normal.

On follow-up, during the next 18 months, the patient's hematologic parameters have remained unchanged. She has received no therapy since she continues to be asymptomatic without organomegaly or signs of hyperviscosity.

\section{Discussion}

The diagnosis of WM in this 36-year-old patient was based upon the presence of anemia, a high ESR, a monoclonal IgM kappa protein, and a bone marrow infiltration with lymphocytes, plasma cells, and plasmacytoid lymphocytes. Although unusual for $\mathrm{WM}^{2{ }^{3}}$ she was asymptomatic and

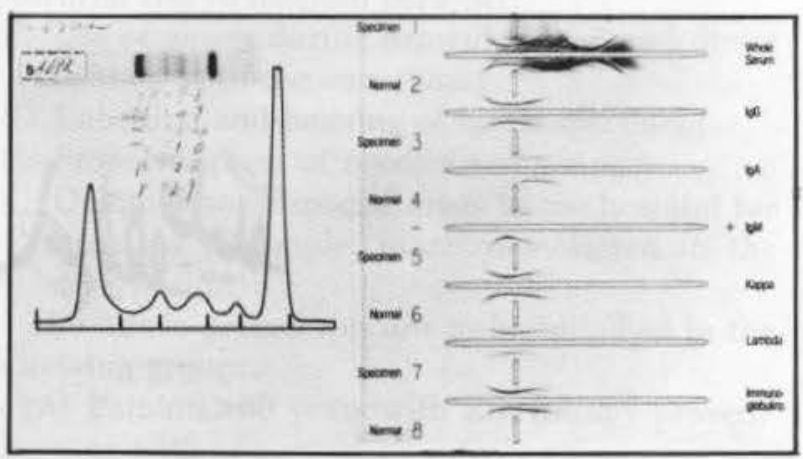

Fig.1 Serum protein electrophoresis (left) shows monoclonal protein peak and immunoelectrophoresis (right) demonstrates a monoclonal IgM kappa protein. 
without organomegaly at diagnosis and during the $1 \frac{1 / 2}{2}$ years of follow-up evaluation. Our patient showed no evidence of a malignant disorder, infectious disease, or connective tissue disorder to explain her IgM paraprotein. Since her episode of infectious mononucleosis was 7 years previously it is unlikely that it was in some way related to her IgM paraproteinemia.

A review of 196 cases of WM demonstrated fatigue, weakness, lymphadenopathy, hepatosplenomegaly, hemorrhage, visual disturbances, and/or occular findings in over $95 \%$ of the cases. ${ }^{4}{ }^{5}$ Less than $5 \%(8 / 196)$ of patients with WM were asymptomatic at the time of diagnosis. ${ }^{458}$ Among these asymptomatic cases, WM was found after evaluation of elevated ESR's. mild anemia, or hyperglobulinemia. ${ }^{5}$ Very rarely puritus has been the only presenting symptom of $\mathrm{WM} .^{78}$ The five asympotmatic patients reported by McCallister et al were followed for 2-9 years without any apparent progession of their $\mathrm{WM},{ }^{5}$ currently similar to our patient.

An investigation of our patients was prompted only by her mild anemia and elevated ESR. Almost $90 \%$ of patients with WM have anemia. ${ }^{58} 1011$ The etiology of anemia can be multifactorial and includes disturbed erythropoiesis, ${ }^{4}$ hemolysis with or without a positive Coomb's test ${ }^{1213}$ and blood loss. ${ }^{413}$ An elevated ESR appears to be universal in WM. ${ }^{10} 1411$

\section{References}

1. Salmon SE, Seligamann M: B-cell neoplasia in man, Lancet $1974 ; 2: 1230$.

2. MacKenzie MR, Fundenberg HH: Macroglobulinemia: an analysis of 40 patients. Blood 1972; 39:874-889.
3. Krajny M, Pruzanski W: Waldenstrom macroglobulinemia: review of 45 cases. Can Med Assoc J 1976; 114-899-905.

4. Imhof JW, Baars H, Verloop MC: Clinical and haematological asspects of macroglobulinemia of Waldenstrom. Acta Med Scand 1959; 163:349.

5. McCallister BD, Bayrd ED, Harrison EG Jr, et al: Primary macroglobulinemia: review with a report on 31 cases and notes on the value of continuous chlorambucil therapy. Am J Med 1967; 43:394-434.

6. Cohen RJ, Bohannon RA and Wallerstein RO: Waldenstrom's macroglobulinemia. A study of 10 cases. Am J Med 1966; 41:274.

7. Glenchur H, Zinneman HH, Briggs DR: Macroglobulinemia: report of 2 cases. An Intern Med 1958; 48:1055.

8. Gassner C, Bittar EE, Parrish AE: Macroglobulinemia and amyloid nephrosis: report of a case. Med Ann District Columbia $1961 ; 30: 342$.

9. Krappeler R, Drebs A, Riva G: Klinik der Makroglobulinamie Waldenstrom. Beschreibung von 21 fallen and ubarsicht der literatur. Helv Med Acta 1958; 25:54.

10. Dutcher TF, Fahey JL: The histopathology of the macroglobulinemia of Waldenstrom. J Natl Cancer Inst $1959 ; 22: 887$.

11. Butler EA, Flynn FV, Harris H and Robson EB: The laboratory diagnosis of macroglobulinaemia with special reference to starchgel electrophoresis. Lancet 1961; 2:289.

12. Aarseth S, Obstad E, Tarvik A: Macroglobulinaemia Waldenstrom: a case with haemolytic syndrome and involvement of the nervous system. Acta Med Scand 1961; 169:691.

13. Cline MJ, Solomon A, Berlin NI, Fahey JL: Anemia in macroglobulinemia. Am J Med 1963; 34:213.

14. Martin NH: Macroglobulinaemia: a clinical pathological study. Quart J Med 1960; 29:179.

Request For Reprints: Abdul N. Memon, M.D., The Memorial Hospital, Pawtucket, RI 02860 